\title{
Clinical application of stem cell therapy in Parkinson's disease
}

\author{
Marios Politis ${ }^{1 *}$ and Olle Lindvall ${ }^{2}$
}

\begin{abstract}
Cell replacement therapies in Parkinson's disease (PD) aim to provide long-lasting relief of patients' symptoms. Previous clinical trials using transplantation of human fetal ventral mesencephalic ( $h f V M$ ) tissue in the striata of PD patients have provided proof-ofprinciple that such grafts can restore striatal dopaminergic (DA-ergic) function. The transplants survive, reinnervate the striatum, and generate adequate symptomatic relief in some patients for more than a decade following operation. However, the initial clinical trials lacked homogeneity of outcomes and were hindered by the development of troublesome graft-induced dyskinesias in a subgroup of patients. Although recent knowledge has provided insights for overcoming these obstacles, it is unlikely that transplantation of hfVM tissue will become routine treatment for PD owing to problems with tissue availability and standardization of the grafts. The main focus now is on producing DA-ergic neuroblasts for transplantation from stem cells (SCs). There is a range of emerging sources of SCs for generating a DA-ergic fate in vitro. However, the translation of these efforts in vivo currently lacks efficacy and sustainability. A successful, clinically competitive SC therapy in PD needs to produce longlasting symptomatic relief without side effects while counteracting PD progression.
\end{abstract}

\section{Introduction}

Parkinson's disease (PD) is a common neurodegenenerative disorder characterized by the classical motor symptoms of bradykinesia, rigidity and tremor. The pathological hallmark of PD is a gradual loss of nigostriatal dopamine (DA) neurons, but neuronal

\footnotetext{
* Correspondence: marios.politis@imperial.ac.uk

${ }^{1}$ Centre for Neuroscience, Department of Medicine, Imperial College London, Hammersmith Hospital, DuCane Road, London W12 ONN, UK Full list of author information is available at the end of the article
}

degeneration also occurs in non-DA-ergic systems [1]. Treatments aiming to relieve PD motor symptoms include the use of oral preparations of L-3,4-dihydroxyphenylalanine (L-DOPA) and DA receptor agonists and, in more advanced cases, the use of apomorphine, delivery of L-DOPA through continuous intestinal administration, and deep brain stimulation in subthalamic nucleus and globus pallidus via surgically implanted electrodes. These treatments have proved effective to a point, but they can generate adverse effects, such as LDOPA-induced dyskinesias, and they do not counteract the progression of the disease.

Series of studies in PD patients with intrastriatal grafts of human fetal ventral mesencephalic (hfVM) tissue have provided proof-of-principle that cell therapy can work in PD patients, that is, that the dead DA neurons can be replaced by new neurons by transplantation [2-5]. The grafts can provide DA-ergic reinnervation of the striatum and symptomatic relief lasting as long as 16 years following transplantation in some patients [2-5] (Figure 1). The most successful operated cases were able to withdraw from L-DOPA therapy. Although some results were promising, the outcomes across the different clinical trials using hfVM tissue have been inconsistent. In addition, the further development of this approach was hindered by the occurrence of adverse effects, so-called graft-induced dyskinesias (GIDs), in a subgroup of patients [6-8]. Even if new, optimized protocols would improve the safety and efficacy in future hfVM tissue trials, it is doubtful whether transplantation of hfVM tissue will become a mainstream treatment for PD due to shortcomings with tissue availability and standardization of the grafts. In this respect, stem cells (SCs) could provide an unlimited source of well-characterized DA neurons for transplantation and therefore overcome these issues (Figure 2). Here, we aim to discuss what we learned from clinical research with hfVM tissue and also review the current status of SC therapy in PD.
C Biomed Central 

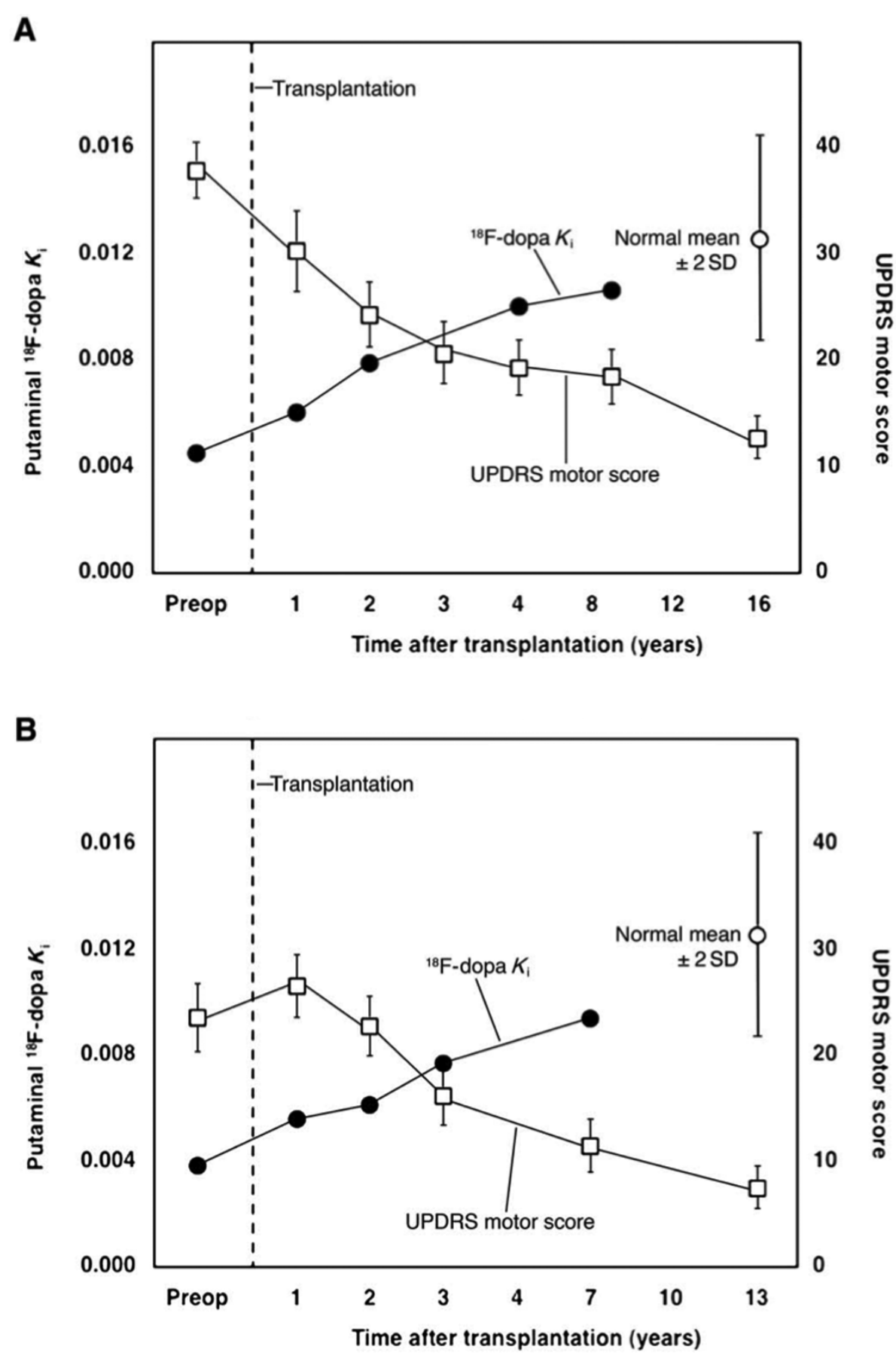

Figure 1 Human fetal ventral mesencephalic tissue grafts provide long-lasting major relief of motor symptoms (reductions in UPDRS motor scores) and restore dopamine innervation (increases in 18F-DOPA PET uptake) in the grafted striatum in Patients 7 (A) and 15 (B) from the Lund series (modified figure from [4]). Patient 7 and Patient 15 stopped receiving any form of dopaminergic medication four and five years following operation, respectively. PET = Positron emission tomography; UPDRS = Unified Parkinson's Disease Rating Scale.

Lessons learned from hfVM tissue clinical trials

Short- and long-term follow-up studies on PD patients subjected to hfVM tissue transplantation have indicated ways of improving the safety and efficacy in future human cell therapy trials. The correct selection of PD patients entering these trials will be of major importance. Positron emission tomography (PET) studies have indicated that the PD patients with the best functional outcome after intrastriatal transplantation of hfVM tissue were the ones in whom the DA-ergic denervation 


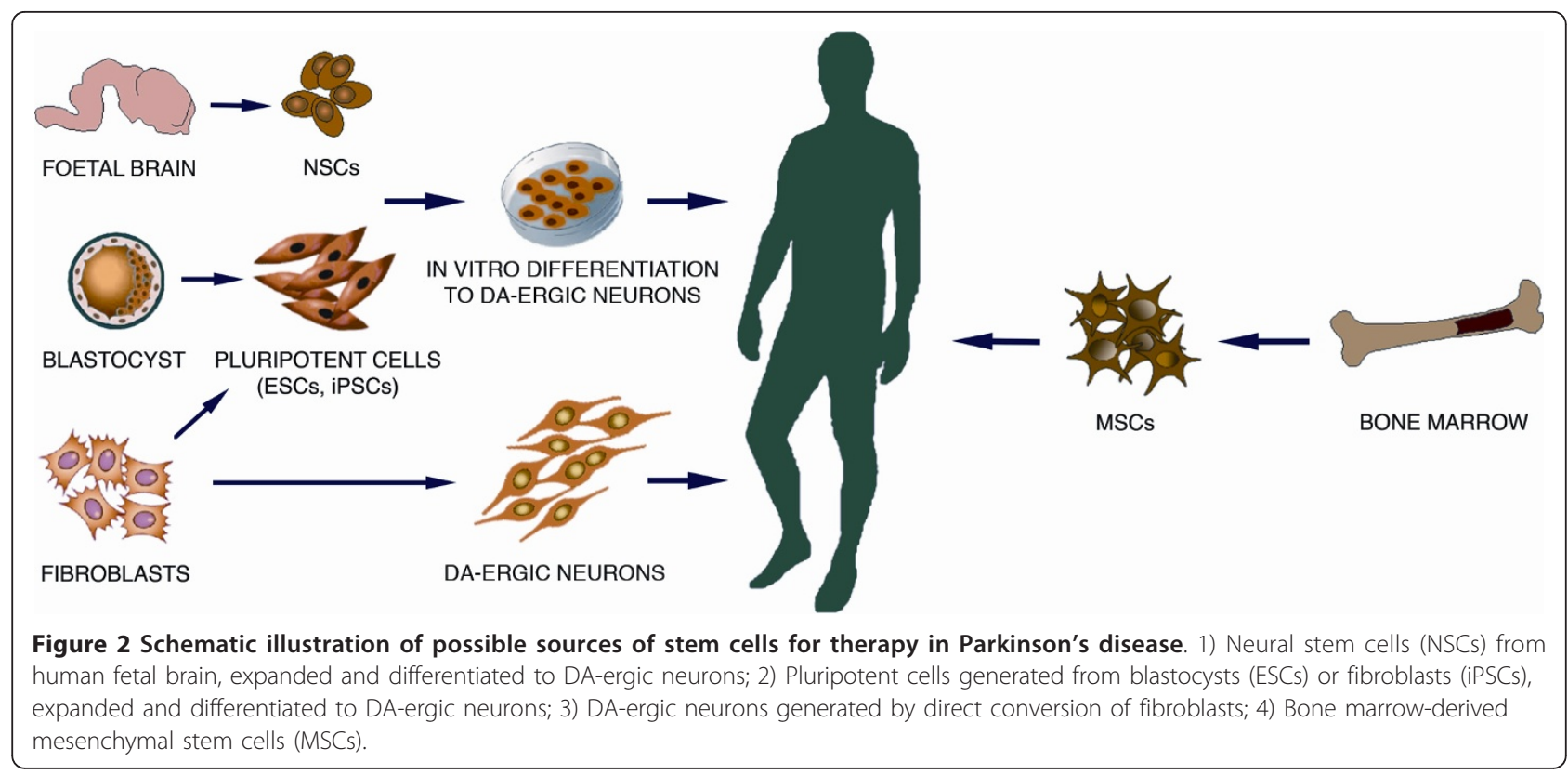

preoperatively was restricted to the dorsal parts of the striatum $[9,10]$. Based on these findings, PD patients with more widespread preoperative DA-ergic denervation, including the ventral striatum, should probably be excluded from these trials, as the predictive outcome would be modest or no clinical benefit.

An important breakthrough was the unveiling of one important mechanism underlying GIDs. Studies utilizing PET and clinical observations in previously transplanted PD patients provided strong evidence that GIDs were caused by a graft-derived striatal serotonergic hyperinnervation, possibly engaging in false DA release, which was also weighted by an unfavorable serotonin/DA transporter ratio $[4,5,11]$. Interestingly, the occurrence of GIDs shows a slow and gradual increase compared to the rapid improvement of motor symptoms following transplantation. This difference is likely due to interactions of serotonin and DA neuronal transmissions because of the gradual expansion of graft-derived serotonergic innervation that takes a leading role in regulating synaptic DA levels in the reinnervated areas $[5,12,13]$.

These findings suggested strategies for avoiding the development of GIDs following DA cell therapy with hfVM tissue or SCs in PD. HfVM tissue contains both dopaminergic and serotonergic neuroblasts [14] and the dissection of hfVM tissue should, therefore, be performed in a way to minimize the serotonergic component. Also, when producing DA neurons from SCs, serotonergic neurons should be kept to a minimum or removed by cell sorting. Moreover, culture and storage of the tissue prior to transplantation could change its composition in favor of non-DA-ergic cells [15]. In accordance, previous studies have reported an increased prevalence of GIDs in patients who received tissue that had been stored for long periods compared to those who received fresh tissue [6,7]. Alternatively, GIDs could be effectively suppressed with systemic administration of serotonin 1A agonists, which dampen transmitter release from serotonergic neurons $[4,5,11]$.

\section{Stem cell therapy in Parkinson's disease}

It remains to be shown whether SC-derived DA neurons can efficiently reinnervate the striatum and provide functional recovery in PD patients. Knowledge from hfVM tissue transplantation in animals and humans has provided a number of requirements for establishing a clinically competitive SC-based therapy in PD. The SC grafts should (a) exhibit a regulated release of DA and molecular, electrophysiological, and morphological properties similar to those of substantia nigra neurons [16,17]; (b) enable survival of more than 100,000 DA neurons per human putamen [18]; (c) reestablish the DA network within the striatum and restore the functional connectivity with host extra-striatal neural circuitries [19]; (d) reverse the motor deficits resembling human symptoms in animal models of PD and induce long-lasting and major symptomatic relief in PD patients; and (e) produce no adverse-effects such as tumor formation, immune reactions and GIDs.

To date, only a few steps have been established towards these goals in vivo. The in vitro generation of SC-derived cells having DA-ergic properties from fetal brain and embryonic SCs (ESCs) and from bone marrow 
SCs has already been shown [20-22] (Figure 2). However, it is unclear whether these cells having DA-ergic properties can be used in PD patients. Table 1 summarizes the advantages and disadvantages of different stem cell types for use in PD.

ESCs are highly proliferative and retain pluripotency after extended periods of in vitro expansion [23]. Since they can give rise to any type of cell in the body including DA-ergic neurons [24-26], their potential to be useful in a clinical setting seems to be great. Rodent and human ESC-derived DA-ergic neurons have been shown to survive transplantation into the striatum of PD rats and generate some degree of functional recovery [27-30]. However, studies have shown that the survival of ESC-derived DA-ergic neurons post-transplantation is relatively low $[27,28,31]$. A major concern with using ESC-derived DA-ergic neurons for transplantation in PD patients is the risk of adverse effects such as tumor formation which has been reported in rats [29,31]. Cell sorting or prolonged differentiation and thereby exhaustion of non-differentiated cell pools in vitro prior to transplantation could potentially reduce the risk of tumor formation [32].

Another promising source of SCs is adult fibroblasts that are reprogrammed to so-called induced pluripotent SCs (iPSCs) [33] and then differentiated to DA-ergic neurons (Figure 2). The iPSC technology has raised the possibility of generating an unlimited source of PD patient-specific DA-ergic neurons, which theoretically also could be used for autologous transplantation [34-37]. DA-ergic neurons were first generated from mouse iPSCs, transplanted into the striatum of a rat PD model and shown to ameliorate functional deficits [36]. Recently, DA-ergic neurons were also produced from iPSCs derived from fibroblasts in adult humans $[38,39]$ and PD patients $[37,40]$. Such neurons survived transplantation into the striatum of PD rodents and produced some degree of functional recovery $[39,40]$. Potential advantages with the use of iPSCs are that PD patient-specific DA neuroblasts could minimize the immune reactions and eliminate the ethical issues associated with the use of human ESCs. However, as with ESCs, the risk for tumor formation needs to be minimized before iPSC-derived DA-ergic neurons can be considered as an option for transplantation in a clinical setting in PD. Moreover, there are concerns about whether the DA-ergic neurons delivered by autologous transplantation in PD would be more susceptible to the disease pathology because genetic mutations could also be present in the fibroblast-derived cells [41,42].

Functional DA-ergic neurons with a substantia nigra phenotype can now also be generated by directly reprogramming mouse and human fibroblasts by expressing neural lineage-specific transcription factors [43-45] (Figure 2). This conversion does not occur through a pluripotent SC stage and thereby the risk of tumor formation is eliminated. Before their clinical use in PD is considered, it is necessary to show that the directly

Table 1 Advantages and disadvantages of different stem cell types for use in Parkinson's disease

\begin{tabular}{|c|c|c|c|}
\hline Stem Cell Type & Definition & Advantages & Disadvantages \\
\hline $\begin{array}{l}\text { Embryonic Stem Cells } \\
\text { (ESCs) }\end{array}$ & $\begin{array}{l}\text { Pluripotent stem cells derived from the inner cell } \\
\text { mass of the blastocyst that are able to differentiate } \\
\text { into cells of the three germ layers and show an } \\
\text { extensive capability for self-renewal without } \\
\text { differentiation, both in vivo and in vitro }\end{array}$ & $\begin{array}{l}\text { (a) Highly proliferative/retain } \\
\text { pluripotency after in vitro } \\
\text { expansion } \\
\text { (b) Can generate DA-ergic } \\
\text { neurons } \\
\text { (c) Shown to survive } \\
\text { transplantation and generate } \\
\text { some degree of functional } \\
\text { recovery }\end{array}$ & (a) Risk of tumor formation \\
\hline $\begin{array}{l}\text { Induced pluripotent Stem } \\
\text { Cells (iPSCs) }\end{array}$ & $\begin{array}{l}\text { Reprogrammed adult murine fibroblasts into ESC-like } \\
\text { cells }\end{array}$ & $\begin{array}{l}\text { (a) Generation of unlimited PD } \\
\text { patient-specific cells/ } \\
\text { autologous transplantation } \\
\text { (b) Shown to survive } \\
\text { transplantation and generate } \\
\text { some degree of functional } \\
\text { recovery } \\
\text { (c) Could minimize immune } \\
\text { reactions and ethical issues }\end{array}$ & $\begin{array}{l}\text { Risk of tumor formation } \\
\text { (b) Autologous transplantation - } \\
\text { risk of susceptibility to the } \\
\text { original pathology of the patient }\end{array}$ \\
\hline $\begin{array}{l}\text { Bone marrow-derived } \\
\text { stromal cells and } \\
\text { mesenchymal Stem Cells } \\
\text { (MSCs) }\end{array}$ & $\begin{array}{l}\text { Small population of cells in the bone marrow that } \\
\text { can differentiate into adipocytes, chondrocytes and } \\
\text { osteoblasts, both in vivo and in vitro }\end{array}$ & $\begin{array}{l}\text { (a) Improve motor } \\
\text { performance in mice } \\
\text { (b) No adverse effects in } \\
\text { humans at } 12 \text { months } \\
\text { following transplantation }\end{array}$ & $\begin{array}{l}\text { (a) Modest clinical improvement } \\
\text { in humans }\end{array}$ \\
\hline $\begin{array}{l}\text { Fetal brain neural Stem } \\
\text { Cells (NSCs) }\end{array}$ & $\begin{array}{l}\text { Multipotent stem cells that are able to differentiate } \\
\text { into neurons, astrocytes and oligodendrocytes }\end{array}$ & $\begin{array}{l}\text { (a) Lower risk of tumor } \\
\text { formation and immune } \\
\text { rejection than ESCS }\end{array}$ & $\begin{array}{l}\text { (a) Shown only limited } \\
\text { differentiation in vivo } \\
\text { (b) Shown only partial effect in } \\
\text { PD-like symptoms }\end{array}$ \\
\hline
\end{tabular}


converted DA-ergic neurons can survive transplantation and give rise to substantial improvements in animal models.

Fetal brain neural SC (NSC)-derived DA-ergic neurons (Figure 2) are associated with lower risk of tumor formation and immune rejection than ESCs [46]. Early studies reported that non-differentiated NSCs taken from a human source and transplanted in rats have limited differentiation in vivo and only partially affect PD-like symptoms [47]. A more recent study showed that nondifferentiated NSCs implanted into PD primates survived, migrated, and had a functional impact [48]. A small number of NSC progeny differentiated into DA phenotypes. The use of developmental signals such as sonic hedgehog, Wnt5a and others in fetal NSC differentiation in vitro enhances the DA-ergic yield and multiple signals can have synergistic effects [49-54]. Production of fetal NSC-derived DA-ergic neurons through well-controlled differentiation protocols in vitro should ensure better homogeneity between grafts.

Bone marrow-derived stromal cells and mesenchymal SCs (MSCs) have been proposed as potential cell sources for transplantation in PD (Figure 2). It has been reported that non-differentiated murine MSCs are able to differentiate into tyrosine hydroxylase-positive neurons and improve motor performance in mice [55]. Also, it has been demonstrated that cells with DA-ergic properties can be produced from both rat and human MSCs, and that transplantation of these cells gave rise to improvement of motor function in an animal model of PD [20]. More recently, a clinical trial in advanced PD patients using unilateral transplantation of autologous bone marrow-derived MSCs into the sublateral ventricular zone reported modest clinical improvement with no adverse effects such as tumor formation at 12 months [56]. In this trial, there were no PET assessments before and after transplantation in order to determine graft survival or changes of DA-ergic striatal function [57]. Thus, the mechanisms underlying the reported modest improvements are completely unknown. Further preclinical work is needed for investigating the ability of MSCs to differentiate into DA-ergic neurons and to reverse functional deficits in animal models.

\section{Conclusions}

Although the ability to restore function in PD patients by DA-ergic neuron replacement has been demonstrated to some extent with hfVM tissue, the focus is now on producing standardized DA-ergic neuroblasts from SCs for transplantation. ESCs and iPSCs seem the simplest to manipulate towards a DA-ergic fate and to produce large numbers of DA-ergic neurons in vitro, but fetal brain NSCs could also be useful for clinical application.
Both iPSC-derived and directly converted DA-ergic neurons have one more advantage as they potentially can be used for autologous transplantation in PD patients.

Several important in vivo properties, which will be decisive for the success or failure of a clinical trial in $\mathrm{PD}$, remain to be demonstrated for human SC-derived DA-ergic neurons in animal models. These include the ability of the SC-derived DA-ergic neurons to substantially reinnervate striatum, restore DA release and markedly improve PD symptoms. Before going ahead with human trials using transplantation of SC-derived DAergic neurons, the risks for tumor formation, immune reactions, and development of GIDs need to be tested and proven minimal. Major research efforts will be needed for the development of a clinically competitive SC-based therapy, which for the first time opens up the possibility for an effective restorative treatment for PD patients.

\section{List of abbreviations}

DA: dopamine; DA-ergic: dopaminergic; ESCs: embryonic stem cells; GIDs: graft-induced dyskinesias; hfVM: human fetal ventral mesencephalic; iPSCs: induced pluripotent stem cells; L-DOPA: L-3,4-dihydroxyphenylalanine; MSCs: mesenchymal stem cells; NSCs: neural stem cells; PD: Parkinson's disease; PET: positron emission tomography; SCs: stem cells.

\section{Acknowledgements}

Our own work was supported by the Medical Research Council UK, the Michael J. Fox Foundation for Parkinson's Research USA, the Swedish Research Council, EU $7^{\text {th }}$ work program through NeuroStemcell (grant no. 22943), and Swedish Government Initiative for Strategic Research Areas (StemTherapy and MultiPark). We thank Prof. Zaal Kokaia for help with Figure 2.

\section{Author details}

${ }^{1}$ Centre for Neuroscience, Department of Medicine, Imperial College London, Hammersmith Hospital, DuCane Road, London W12 ONN, UK. ${ }^{2}$ Laboratory of Neurogenesis and Cell Therapy, Wallenberg Neuroscience Center and Lund Stem Cell Center, University Hospital, SE-221 84 Lund, Sweden.

\section{Authors' contributions}

$\mathrm{MP}$ and $\mathrm{OL}$ are equally responsible for the content of this article. Both authors read and approved the final manuscript.

\section{Competing interests}

The authors declare that they have no competing interests.

Received: 27 July 2011 Accepted: 4 January 2012

Published: 4 January 2012

\section{References}

1. Politis M, Wu K, Loane C, Kiferle L, Molloy S, Brooks DJ, Piccini P: Staging of serotonergic dysfunction in Parkinson's disease: an in vivo 11C-DASB PET study. Neurobiol Dis 2010, 40:216-221.

2. Dunnett SB, Björklund A, Lindvall O: Cell therapy in Parkinson's disease stop or go? Nat Rev Neurosci 2001, 2:365-369.

3. Lindvall O, Björklund A: Cell therapy in Parkinson's disease. NeuroRx 2004 1:382-393

4. Politis M, Wu K, Loane C, Quinn NP, Brooks DJ, Rehncrona S, Bjorklund A, Lindvall O, Piccini P: Serotonergic neurons mediate dyskinesia side effects in Parkinson's patients with neural transplants. Sci Trans/ Med 2010, 2:38ra46.

5. Politis M, Oertel WH, Wu K, Quinn NP, Pogarell O, Brooks DJ, Bjorklund A, Lindvall O, Piccini P: Graft-induced dyskinesias in Parkinson's disease: 
High striatal serotonin/dopamine transporter ratio. Mov Disord 2011, 11:1997-2003.

6. Freed CR, Greene PE, Breeze RE, Tsai WY, DuMouchel W, Kao R, Dillon S, Winfield H, Culver S, Trojanowski JQ, Eidelberg D, Fahn S: Transplantation of embryonic dopamine neurons for severe Parkinson's disease. N Engl J Med 2001, 344:710-719.

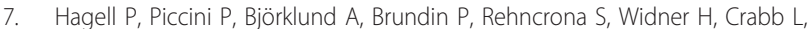
Pavese N, Oertel WH, Quinn N, Brooks DJ, Lindvall O: Dyskinesias following neural transplantation in Parkinson's disease. Nat Neurosci 2002, 5:627-628

8. Olanow CW, Goetz CG, Kordower JH, Stoessl AJ, Sossi V, Brin MF, Shannon KM, Nauert GM, Perl DP, Godbold J, Freeman TB: A double-blind controlled trial of bilateral fetal nigral transplantation in Parkinson's disease. Ann Neurol 2003, 54:403-414.

9. Piccini P, Pavese N, Hagell P, Reimer J, Björklund A, Oertel WH, Quinn NP, Brooks DJ, Lindvall O: Factors affecting the clinical outcome after neural transplantation in Parkinson's disease. Brain 2005, 128:2977-2986.

10. Ma Y, Tang C, Chaly T, Greene P, Breeze R, Fahn S, Freed C, Dhawan V, Eidelberg D: Dopamine cell implantation in Parkinson's disease: longterm clinical and (18)F-FDOPA PET outcomes. J Nucl Med 2010, 51:7-15.

11. Politis M: Dyskinesias after neural transplantation in Parkinson's disease: what do we know and what is next? BMC Med 2010, 8:80.

12. Daszuta A, Strecker RE, Brundin P, Björklund A: Serotonin neurons grafted to the adult rat hippocampus. I. Time course of growth as studied by immunohistochemistry and biochemistry. Brain Res 1988, 458:1-19.

13. Carlsson T, Carta M, Winkler C, Björklund A, Kirik D: Serotonin neuron transplants exacerbate L-DOPA-induced dyskinesias in a rat model of Parkinson's disease. J Neurosci 2007, 27:8011-8022.

14. Braak H, Del Tredici K: Assessing fetal nerve cell grafts in Parkinson's disease. Nat Med 2008, 14:483-485.

15. Fawcett JW, Barker RA, Dunnett SB: Dopaminergic neuronal survival and the effects of bFGF in explant, three dimensional and monolayer cultures of embryonic rat ventral mesencephalon. Exp Brain Res 1995, 106:275-282.

16. Isacson O, Bjorklund LM, Schumacher JM: Toward full restoration of synaptic and terminal function of the dopaminergic system in Parkinson's disease by stem cells. Ann Neurol 2003, 53(Suppl 3):135-148.

17. Mendez I, Sanchez-Pernaute R, Cooper O, Viñuela A, Ferrari D, Björklund L, Dagher A, Isacson O: Cell type analysis of functional fetal dopamine cell suspension transplants in the striatum and substantia nigra of patients with Parkinson's disease. Brain 2005, 128:1498-1510.

18. Hagell $P$, Brundin P: Cell survival and clinical outcome following intrastriatal transplantation in Parkinson disease. J Neuropathol Exp Neurol 2001, 60:741-752.

19. Piccini $P$, Lindvall $O$, Björklund $A$, Brundin $P$, Hagell $P$, Ceravolo R, Oertel W, Quinn N, Samuel M, Rehncrona S, Widner H, Brooks DJ: Delayed recovery of movement-related cortical function in Parkinson's disease after striatal dopaminergic grafts. Ann Neurol 2000, 48:689-695.

20. Dezawa M, Kanno H, Hoshino M, Cho H, Matsumoto N, Itokazu Y, Tajima N, Yamada $H$, Sawada $H$, Ishikawa $H$, Mimura T, Kitada M, Suzuki $Y$, Ide $C$ Specific induction of neuronal cells from bone marrow stromal cells and application for autologous transplantation. J Clin Invest 2004, 113:1701-1710

21. Lindvall O, Kokaia Z, Martinez-Serrano A: Stem cell therapy for human neurodegenerative disorders-how to make it work. Nat Med 2004, 10(Suppl):S42-50.

22. Takagi Y, Takahashi J, Saiki H, Morizane A, Hayashi T, Kishi Y, Fukuda H, Okamoto $Y$, Koyanagi M, Ideguchi M, Hayashi H, Imazato T, Kawasaki H, Suemori H, Omachi S, lida H, Itoh N, Nakatsuji N, Sasai Y, Hashimoto N: Dopaminergic neurons generated from monkey embryonic stem cells function in a Parkinson primate model. J Clin Invest 2005, 115:102-109.

23. Amit M, Carpenter MK, Inokuma MS, Chiu CP, Harris CP, Waknitz MA, Itskovitz-Eldor J, Thomson JA: Clonally derived human embryonic stem cell lines maintain pluripotency and proliferative potential for prolonged periods of culture. Dev Biol 2000, 227:271-278.

24. Park S, Lee KS, Lee YJ, Shin HA, Cho HY, Wang KC, Kim YS, Lee HT, Chung KS, Kim EY, Lim J: Generation of dopaminergic neurons in vitro from human embryonic stem cells treated with neurotrophic factors. Neurosci Lett 2004, 359:99-103.
25. Perrier AL, Tabar V, Barberi T, Rubio ME, Bruses J, Topf N, Harrison NL, Studer $\mathrm{L}$ : Derivation of midbrain dopamine neurons from human embryonic stem cells. Proc Natl Acad Sci USA 2004, 101:12543-12548.

26. Cho MS, Lee YE, Kim JY, Chung S, Cho YH, Kim DS, Kang SM, Lee H, Kim MH, Kim JH, Leem JW, Oh SK, Choi YM, Hwang DY, Chang JW, Kim DW: Highly efficient and large-scale generation of functional dopamine neurons from human embryonic stem cells. Proc Natl Acad Sci USA 2008, 105:3392-3397.

27. Kim JH, Auerbach JM, Rodríguez-Gómez JA, Velasco I, Gavin D, Lumelsky N, Lee SH, Nguyen J, Sánchez-Pernaute R, Bankiewicz K, McKay R: Dopamine neurons derived from embryonic stem cells function in an animal model of Parkinson's disease. Nature 2002, 418:50-56.

28. Ben-Hur T, Idelson M, Khaner H, Pera M, Reinhartz E, Itzik A, Reubinoff BE: Transplantation of human embryonic stem cell-derived neural progenitors improves behavioral deficit in Parkinsonian rats. Stem Cells 2004, 22:1246-1255.

29. Roy NS, Cleren C, Singh SK, Yang L, Beal MF, Goldman SA: Functional engraftment of human ES cell-derived dopaminergic neurons enriched by coculture with telomerase-immortalized midbrain astrocytes. Nat Med 2006, 12:1259-1268.

30. Yang D, Zhang ZJ, Oldenburg M, Ayala M, Zhang SC: Human embryonic stem cell-derived dopaminergic neurons reverse functional deficit in parkinsonian rats. Stem Cells 2008, 26:55-63.

31. Brederlau A, Correia AS, Anisimov SV, Elmi M, Paul G, Roybon L, Morizane A, Bergquist F, Riebe I, Nannmark U, Carta M, Hanse E, Takahashi J, Sasai Y, Funa K, Brundin P, Eriksson PS, Li JY: Transplantation of human embryonic stem cell-derived cells to a rat model of Parkinson's disease: effect of in vitro differentiation on graft survival and teratoma formation. Stem Cells 2006, 24:1433-1440.

32. Hedlund E, Pruszak J, Lardaro T, Ludwig W, Viñuela A, Kim KS, Isacson O: Embryonic stem cell-derived Pitx3-enhanced green fluorescent protein midbrain dopamine neurons survive enrichment by fluorescenceactivated cell sorting and function in an animal model of Parkinson's disease. Stem Cells 2008, 26:1526-1536.

33. Takahashi K, Yamanaka S: Induction of pluripotent stem cells from mouse embryonic and adult fibroblast cultures by defined factors. Cell 2006, 126:663-676

34. Park $\mathrm{H}$, Arora N, Huo H, Maherali N, Ahfeldt T, Shimamura A, Lensch MW, Cowan C, Hochedlinger K, Daley GQ: Disease-specific induced pluripotent stem cells. Cell 2008, 134:877-886.

35. Tabar V, Tomishima M, Panagiotakos G, Wakayama S, Menon J, Chan B, Mizutani E, Al-Shamy G, Ohta H, Wakayama T, Studer L: Therapeutic cloning in individual parkinsonian mice. Nat Med 2008, 14:379-381.

36. Wernig M, Zhao JP, Pruszak J, Hedlund E, Fu D, Soldner F, Broccoli V, Constantine-Paton $\mathrm{M}$, Isacson $\mathrm{O}$, Jaenisch $\mathrm{R}$ : Neurons derived from reprogrammed fibroblasts functionally integrate into the fetal brain and improve symptoms of rats with Parkinson's disease. Proc Natl Acad Sci USA 2008, 105:5856-5861.

37. Soldner F, Hockemeyer D, Beard C, Gao Q, Bell GW, Cook EG, Hargus G, Blak A, Cooper O, Mitalipova M, Isacson O, Jaenisch R: Parkinson's disease patient-derived induced pluripotent stem cells free of viral reprogramming factors. Cell 2009, 136:964-977.

38. Cai J, Yang M, Poremsky E, Kidd S, Schneider JS, lacovitti L: Dopaminergic neurons derived from human induced pluripotent stem cells survive and integrate into 6-OHDA-lesioned rats. Stem Cells Dev 2010, 19:1017-1023.

39. Swistowski A, Peng J, Liu Q, Mali P, Rao MS, Cheng L, Zeng X: Efficient generation of functional dopaminergic neurons from human induced pluripotent stem cells under defined conditions. Stem Cells 2010, 28:1893-1904.

40. Hargus G, Cooper O, Deleidi M, Levy A, Lee K, Marlow E, Yow A, Soldner F, Hockemeyer D, Hallett PJ, Osborn T, Jaenisch R, Isacson O: Differentiated Parkinson patient-derived induced pluripotent stem cells grow in the adult rodent brain and reduce motor asymmetry in Parkinsonian rats. Proc Natl Acad Sci USA 2010, 107:15921-15926.

41. Li JY, Englund E, Holton JL, Soulet D, Hagell P, Lees AJ, Lashley T, Quinn NP, Rehncrona S, Björklund A, Widner H, Revesz T, Lindvall O, Brundin P: Lewy bodies in grafted neurons in subjects with Parkinson's disease suggest host-to-graft disease propagation. Nat Med 2008, 14:501-503. 
42. Kordower JH, Chu Y, Hauser RA, Freeman TB, Olanow CW: Lewy body-like pathology in long-term embryonic nigral transplants in Parkinson's disease. Nat Med 2008, 14:504-506.

43. Vierbuchen T, Ostermeier A, Pang ZP, Kokubu Y, Südhof TC, Wernig M: Direct conversion of fibroblasts to functional neurons by defined factors. Nature 2010, 463:1035-1041.

44. Pfisterer U, Kirkeby A, Torper O, Wood J, Nelander J, Dufour A, Björklund A Lindvall O, Jakobsson J, Parmar M: Direct conversion of human fibroblasts to dopaminergic neurons. Proc Natl Acad Sci USA 2011, 108:10343-10348.

45. Caiazzo M, Dell'anno MT, Dvoretskova E, Lazarevic D, Taverna S, Leo D, Sotnikova TD, Menegon A, Roncaglia P, Colciago G, Russo G, Carninci P, Pezzoli G, Gainetdinov RR, Gustincich S, Dityatev A, Broccoli V: Direct generation of functional dopaminergic neurons from mouse and human fibroblasts. Nature 2011, 476:224-227.

46. Mimeault M, Batra SK: Concise review: recent advances on the significance of stem cells in tissue regeneration and cancer therapies. Stem Cells 2006, 24:2319-2345.

47. Svendsen CN, Caldwell MA, Shen J, ter Borg MG, Rosser AE, Tyers $P$, Karmiol S, Dunnett SB: Long-term survival of human central nervous system progenitor cells transplanted into a rat model of Parkinson's disease. Exp Neurol 1997, 148:135-146.

48. Redmond DE Jr, Bjugstad KB, Teng YD, Ourednik V, Ourednik J, Wakeman DR, Parsons XH, Gonzalez R, Blanchard BC, Kim SU, Gu Z, Lipton SA, Markakis EA, Roth RH, Elsworth JD, Sladek JR Jr, Sidman RL, Snyder EY: Behavioral improvement in a primate Parkinson's model is associated with multiple homeostatic effects of human neural stem cells. Proc Natl Acad Sci USA 2007, 104:12175-12180.

49. Wang $M Z$, Jin $P$, Bumcrot DA, Marigo V, McMahon AP, Wang EA, Woolf $T$, Pang $K$ : Induction of dopaminergic neuron phenotype in the midbrain by Sonic hedgehog protein. Nat Med 1995, 1:1184-1188.

50. Ye W, Shimamura K, Rubenstein JL, Hynes MA, Rosenthal A: FGF and Shh signals control dopaminergic and serotonergic cell fate in the anterior neural plate. Cell 1998, 93:755-766.

51. Andersson EK, Irvin DK, Ahlsiö J, Parmar M: Ngn2 and Nurr1 act in synergy to induce midbrain dopaminergic neurons from expanded neural stem and progenitor cells. Exp Cell Res 2007, 313:1172-1180

52. O'Keeffe FE, Scott SA, Tyers P, O'Keeffe GW, Dalley JW, Zufferey R, Caldwell MA: Induction of A9 dopaminergic neurons from neural stem cells improves motor function in an animal model of Parkinson's disease. Brain 2008, 131:630-641.

53. Parish CL, Castelo-Branco G, Rawal N, Tonnesen J, Sorensen AT, Salto C, Kokaia M, Lindvall O, Arenas E: Wnt5a-treated midbrain neural stem cells improve dopamine cell replacement therapy in parkinsonian mice. J Clin Invest 2008, 118:149-160.

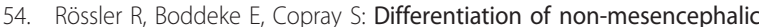
neural stem cells towards dopaminergic neurons. Neuroscience 2010, 170:417-428.

55. Li Y, Chen J, Wang L, Zhang L, Lu M, Chopp M: Intracerebral transplantation of bone marrow stromal cells in a 1-methyl-4-phenyl1,2,3,6-tetrahydropyridine mouse model of Parkinson's disease. Neurosc Lett 2001, 316:67-70.

56. Venkataramana NK, Kumar SK, Balaraju S, Radhakrishnan RC, Bansal A, Dixit A, Rao DK, Das M, Jan M, Gupta PK, Totey SM: Open-labeled study of unilateral autologous bone-marrow-derived mesenchymal stem cell transplantation in Parkinson's disease. Trans/ Res 2010, 155:62-70.

57. Politis M: Optimizing functional imaging protocols for assessing the outcome of fetal cell transplantation in Parkinson's disease. BMC Med 2011, 9:50

Pre-publication history

The pre-publication history for this paper can be accessed here: http://www.biomedcentral.com/1741-7015/10/1/prepub

doi:10.1186/1741-7015-10-1

Cite this article as: Politis and Lindvall: Clinical application of stem cell therapy in Parkinson's disease. BMC Medicine 2012 10:1.

\section{Submit your next manuscript to BioMed Central and take full advantage of:}

- Convenient online submission

- Thorough peer review

- No space constraints or color figure charges

- Immediate publication on acceptance

- Inclusion in PubMed, CAS, Scopus and Google Scholar

- Research which is freely available for redistribution

Submit your manuscript at www.biomedcentral.com/submit 